\title{
SUSTAINABILITY REPORTING PRACTICES WITH SPECIAL REFERENCE TO CEMENT INDUSTRY IN INDIA
}

\author{
Ms. Krishna Oza, Dr. Marzun Jokhi \\ Research Scholar, \\ GLS University, Ahmedabad \\ Principal, Faculty of Commerce, \\ GLS University, Ahmedabad
}

\begin{abstract}
Over recent years, there has been a focus in corporate activity upon the concept of sustainability reporting. Sustainability reporting has gained importance by Indian companies and corporates have adopted sustainability reporting practices since few years. Sustainability reporting of an organisations provides information about discharge of social reasonability and level of sensitivity of organisations towards social and environmental issues. Though sustainability reporting is not compulsory in the country many companies are reporting their initiatives in the direction of sustainable development. This paper attempt to evaluate sustainability reporting by leading Cement Manufacturing companies. This paper describes reporting pattern of cement industry in India.
\end{abstract}

Keywords: Sustainability, sustainability reporting, Cement industry, Cement Sustainability Initiative

\section{INTRODUCTION}

India is the second largest producer of cement in the world. No wonder, India's cement industry is a vital part of its economy, providing employment to more than a million people, directly or indirectly. Ever since it was deregulated in 1982, the Indian cement industry has attracted huge investments, both from Indian as well as foreign investors.

India has a lot of potential for development in the infrastructure and construction sector and the cement sector is expected to largely benefit from it. Some of the recent major government initiatives such as development of 98 smart cities are expected to provide a major boost to the sector.

Expecting such developments in the country and aided by suitable government foreign policies, several foreign players such as Lafarge-Holcim, Heidelberg Cement, and Vicat have invested in the country in the recent past. A significant factor which aids the growth of this sector is the ready availability of the raw materials for making cement, such as limestone and coal.

\section{MARKET SIZE OF CEMENT INDUSTRIES}

Cement prices in India recorded a 6.7 per cent month-on-month growth in April 2017, thereby indicating the probability of growth in volume and profitability of cement companies in the quarter ending June 2017. The housing sector is the biggest demand driver of cement, accounting for about 67 per cent of the total consumption in India. The other major consumers of cement include infrastructure at 13 per cent, commercial construction at 11 per cent and industrial construction at 9 per cent.

The cement capacity in India is estimated to be at 420 MT as of March 2017 with production growing at 5-6 per cent per year. The country's per capita consumption stands at around $225 \mathrm{~kg}$.

The Indian cement industry is dominated by a few companies. The top 20 cement companies account for almost 70 per cent of the total cement production of the country. A total of 188 large cement plants together account for 97 per cent of the total installed capacity in the country, with 365 small plants account for the rest. Of these large cement plants, 77 are located in the states of Andhra Pradesh, Rajasthan and Tamil Nadu. 


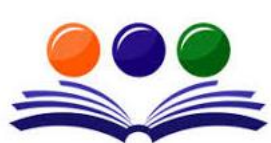

GRAND ACADEMIC PORTAL RESEARCH JOURNALS

A GLOBAL JOURNAL OF SOCIAL SCIENCES

( ISSN - 2581-5830 )

Impact Factor - SJIF - 4.998, IIFS - 4.375

Globally peer-reviewed and open access journal.

Market Overview

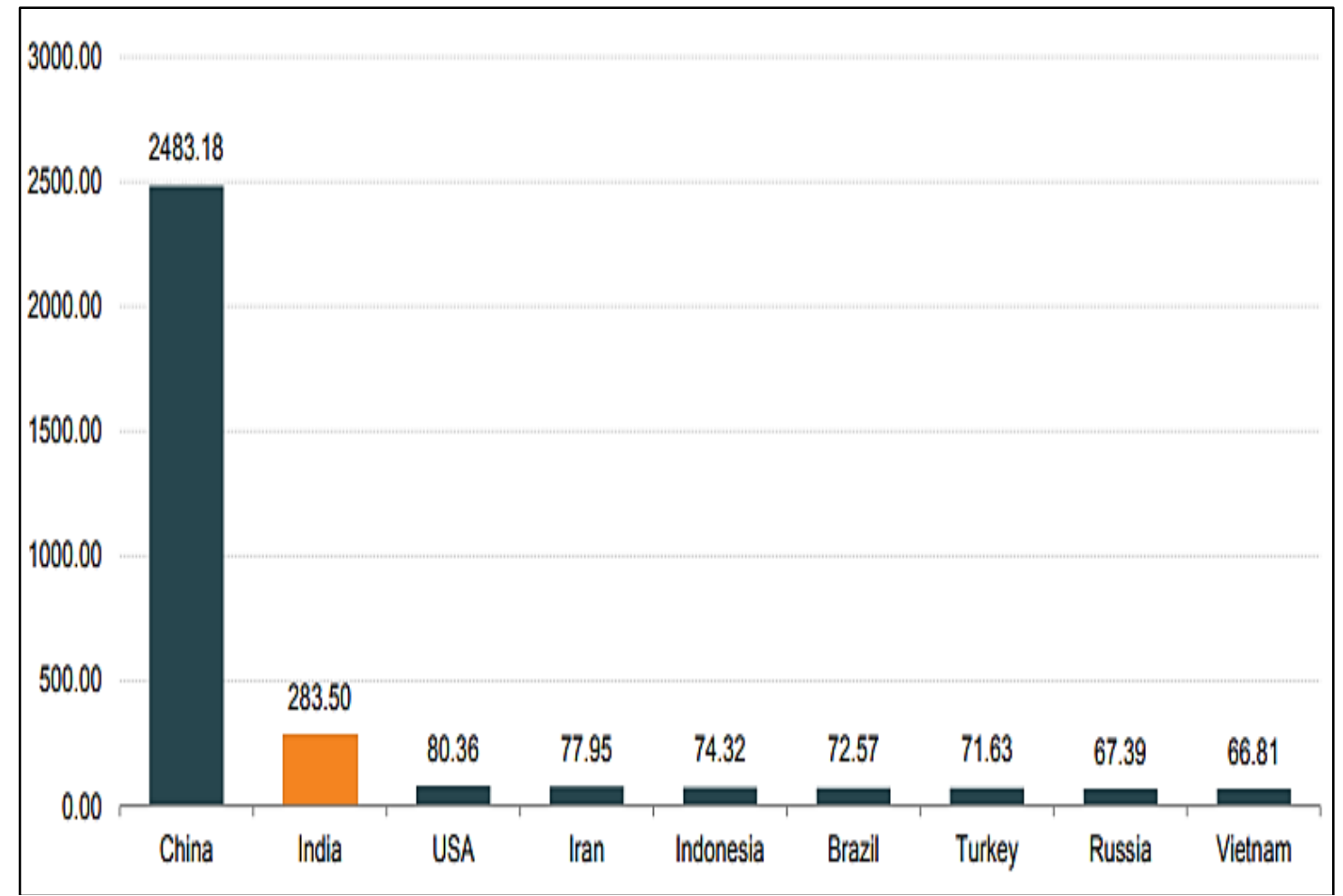

Figure 3.1- Top Cement Producers in FY16 (in MTPA)

- India - world's 2nd largest cement market, both in production and consumption.

- Supported by high level of activity going on in real estate and high government spending on smart cities and urban infrastructure.

- A total of 575 operational cement plants in the country.

- Capacity of 453.4 MTPA as of 2017.

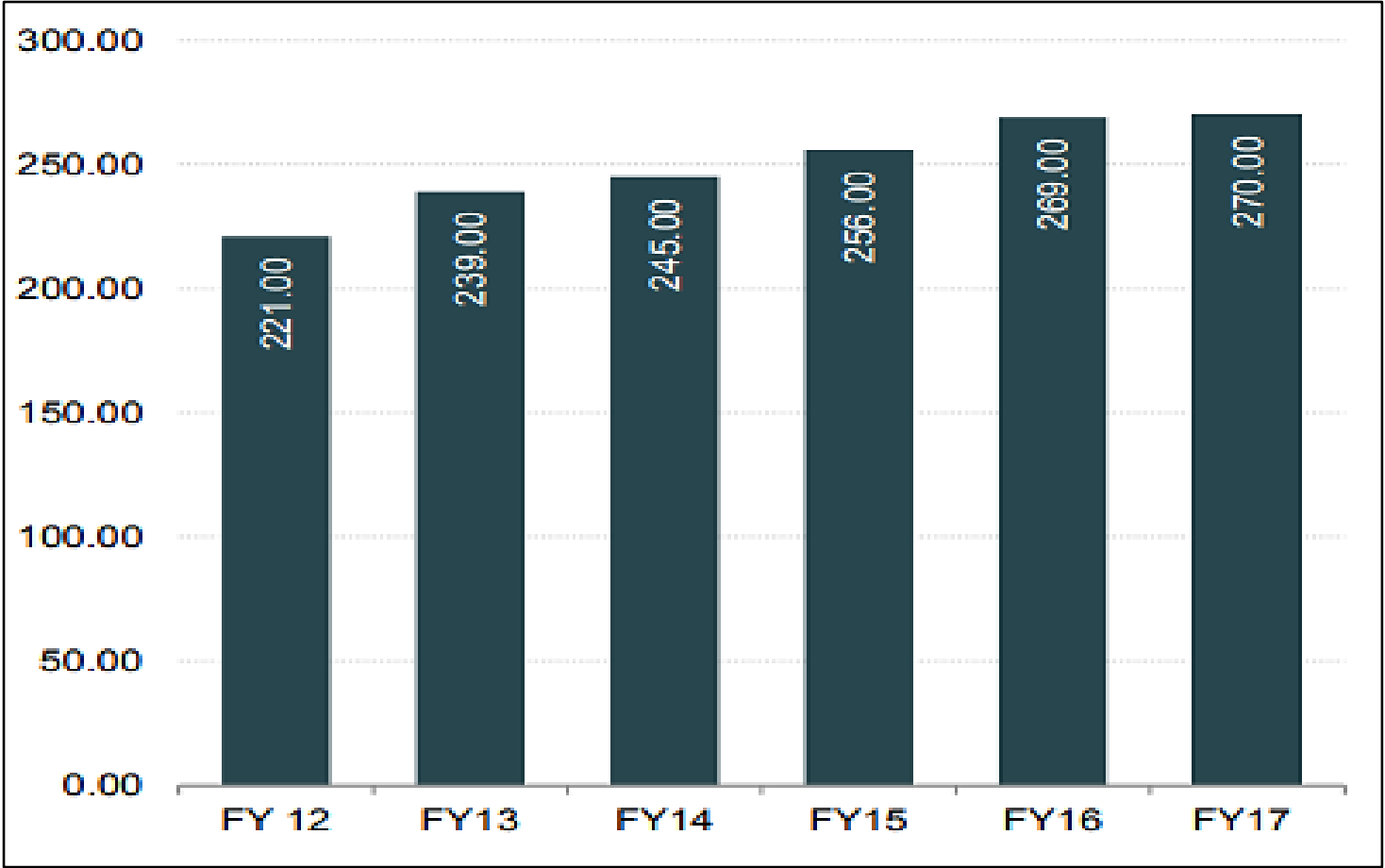

Figure 3.1 - Cement consumption (million tonnes) 


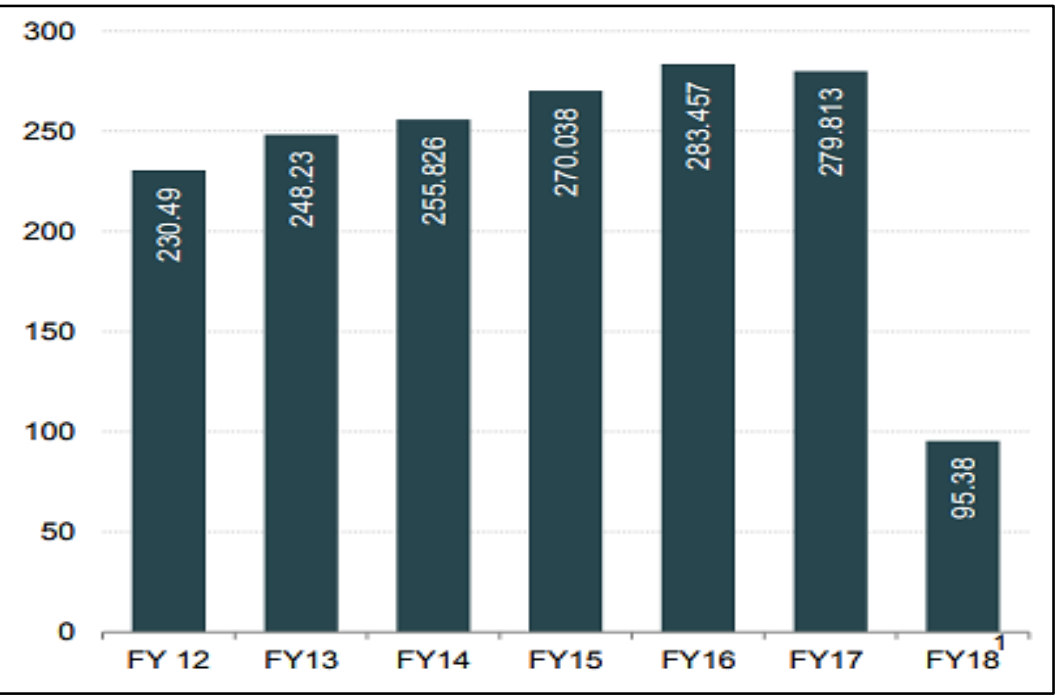

Figure 2.3 - Cement Production in India (million tonnes)

\section{INVESTMENTS}

On the back of growing demand, due to increased construction and infrastructural activities, the cement sector in India has seen many investments and developments in recent times.

According to data released by the Department of Industrial Policy and Promotion (DIPP), cement and gypsum products attracted Foreign Direct Investment (FDI) worth US\$ 5.24 billion between April 2000 and March 2017.

Some of the major investments in Indian cement industry are as follows:

- Emami Ltd, a fast-moving consumer goods (FMCG) company, plans to invest around Rs 8,500 crore (US\$1.32 billion) to scale up its cement production capacity from 2.4 million tonnes (MT) to 15-20 MT in the next three to five years.

-The Gujarat-based Nirma group, with presence in detergent, soap and chemicals sector, has bought Lafarge India's cement business, consisting of 11 MT production capacity, for US\$ 1.4 billion.

-FLSmidth, a global engineering company based in Copenhagen, has signed a contract with India's Larsen \& Toubro Limited for engineering, procurement and supply of equipment for a complete cement production line with a capacity of 3,000 tonne in Tamil Nadu.

\section{GOVERNMENT INITIATIVES}

In the 12th Five Year Plan, the Government of India plans to increase investment in infrastructure to the tune of US\$ 1 trillion and increase the industry's capacity to 150 MT.

The Cement Corporation of India (CCI) was incorporated by the Government of India in 1965 to achieve selfsufficiency in cement production in the country. Currently, CCI has 10 units spread over eight states in India. In order to help the private sector companies thrive in the industry, the government has been approving their investment schemes. Some such initiatives by the government in the recent past are as follows:

The State Government of Chattisgarh has auctioned one block of Limestone (Kesla II) in Raipur District having estimated reserves of 215 million tonnes valued at Rs 10,367crore (US\$ 1.61 billion), and would earn a cumulative revenue of Rs 11,894 crore (US\$ 1.85 billion) to State Government over the lease period.

The Union Budget proposed to assign infrastructure status to affordable housing projects and facilitate higher investments and better credit facilities, in line with the government's aim to provide housing for all by 2022 which will boost cement demand.

The Finance Minister, Arun Jaitley, said that the National Housing Bank will refinance individual housing loans of about Rs 20,000 crore (US\$ 3 billion) in 2017-18. The Finance Minister proposed to complete 1 crore houses by 2019. All these developments are expected to boost cement demand.

The increased allocation to rural low-cost housing under Pradhan Mantri Awaas Yojana- Gramin scheme to Rs 23,000 crore (US\$ 3.45 billion) from Rs 16,000 crore (US\$ 2.4 billion) in FY17 is likely to drive a 2 per cent increase in cement demand, Ambit Capital said in a report. 


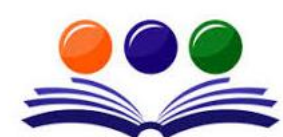

GRAND ACADEMIC PORTAL RESEARCH JOURNALS

\section{SUSTAINABILITY REPORTING CONCEPT IN INDIA}

A sustainability report is an organizational report that gives information about economic, environmental, social and governance performance. Sustainability reporting prepared for internal and external stakeholders is not just report generation from collected data; instead it is a method to internalize and improve an organization's commitment to sustainable development. In other words, Sustainability Reporting is disclosure of the attempts made by an organization on environmental reporting, human resource reporting, reporting on social \& governance performance, reporting on sustainability issues either in a separate report or integrated with the annual financial report.

In recent years, the growing concerns for environmental and climate change, have pressurized the corporates to be accountable and transparent, and to disclose a wide variety of information about activities, including their sustainability. For the purposes, sustainability reporting is the only communication tool through which corporations make their corporate social-responsibility (CSR) activities, including social and environmental impacts in addition to financial performance.

The reporting scenario in India is still in nascent stage with nearly 217 companies disclosing their sustainability performance. Sectors that lead the reporting initiative in India include cement, construction and building material, metals and mining, oil and gas and chemicals while sectors like transportation, finance, trade and retail and communications and media have few reports.

However, the industry has been showing positive signs in embracing this concept and recent policy developments including 'National Voluntary Guidelines on Social, Environmental and Economical Responsibilities of Business' will bolster the reporting efforts in India.

Across the world economic considerations, innovative practices, employee motivation-morale boosting and cost savings are some of key business drivers for companies to adopt sustainability; in India it has been observed that strengthening reputation and brand and ethical considerations prompt companies to embrace this concept.

\section{SUSTAINABILITY REPORTING - A REQUIREMENT IN CEMENT INDUSTRY}

- The challenge for cement companies is to balance the growing demand for cement with its environmental implications by developing and championing sustainable solutions for the industry.

- Meeting the growing demand for cement without harming environment is the biggest challenge for cement industries.

- Considering the increase in demand of cement the issues like safety, waste management, energy reduction, water conservation, biodiversity management, afforestation and emission reduction are to be taken care of for a sustainable business in cement industry.

- Seeking resort to sustainable solutions is the only option for cement industries.

- Thus, In India, UltraTech Cement, Shree Cement, are members of Cement Sustainability Initiative (CSI). Members of such voluntary association makes an attempt to disclose several aspects of Sustainable reporting.

- $\quad$ Cement Industry is the industry which is generating highest wastage with polluting environment in the country. Hence conscious ness of the Organisation towards environmental aspect is much more important.

\section{LITERATURE REVIEW}

Neeraj Goyal (2014) in his paper "Corporate Sustainability reporting practice among Indian companies Myth or Reality" attempts to find out level of corporate disclosure in India. It is seen that environmental reporting is been given importance. Disclosure of environmental issues in Annual report is a fundamental requirement for a company in order to satisfy the information needs of its stakeholders Though there is a lot of variation in the disclosure practice between various industries. As there is no framework, less standardization is there some items have high disclosure and other items are totally ignored.

Gautam R. \& Singh A. (2010) undertook a research on 500 Indian companies to explore the various definitions and descriptions of Corporate Social responsibility. The study aims at identifying key Corporate Social responsibility practices and matches these against Global Reporting Initiative standards. The findings were CSR is now included in business strategy. Cause of including CSR as business strategy is stakeholders pressure. CSR vary with company's size, turnover and profits. out of the sample 500 companies only 271 companies were reporting non-financial activities out of which only $49 \%$ prepared CSR report. Of this $49 \%$ 


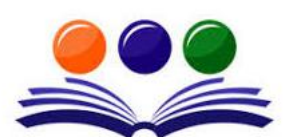

GRAND ACADEMIC PORTAL RESEARCH JOURNALS

A GLOBAL JOURNAL OF SOCIAL SCIENCES

( ISSN - 2581-5830 )

Impact Factor - SJIF - 4.998, IIFS - 4.375

Globally peer-reviewed and open access journal.

many companies are making token gestures on CSR and few are preparing report in a structured and detailed manner. Every company prepares sustainability report in its own way.

Jose P. \& Haimashree (2014) analysed sustainability related information disclosed by top 100 Global Fortune 500 companies. It laid emphasis on surveying green operations, environmental conservation and philanthropy information. Green operation and environmental conservation disclosure were high as compared to infrastructural development in both Indian \& Global cases. It was also noticed that global companies were better in terms of environmental disclosure.

Kolk (2003) undertook a research on Fortune Global 250 companies. To what extent \& how these companies follows sustainability reporting practices is examined here. Majority multinationals, especially Europe and Japan, have started paying attention on structuring sustainability responsibilities, compliance, ethics and external verification. Though there is lack of detailing in disclosures, some notable practices can be found. Underlying dilemmas and complexities for managers in dealing with accountability to shareholders and stakeholders, was observed.

Kumar V. et al (2015) undertook a research on sustainability reporting by comparing 36 Indian companies from 10 different sectors. Diversification was found in sustainability reporting across sectors on the broader dimensions. All the reports were examined with context to dimensions (economic, social, environmental) \& the group of stakeholders. Nature and type of business of companies found to be the main reason for difference in sustainability reports of different sectors.

Japee (2017) The growth in environmental accounting research and interest in the last few years has been little short of phenomenal. The review of prior research shows that the major contributions have been related to the motivations for social and environmental disclosure. However, other important research areas such ethical/accountability issues and how to cost externalities which have already been considered within the context of developed countries are yet to emerge within the developing country context.

Tripathi \& Japee (2020) In India capital market provide various investment avenues to the investors, to assist them to take a position in various industries and to make sure the profitable return. Among various financial products, open-end fund ensures the minimum risks and maximum return to the investors, Growth, and developments of varied mutual funds products has proved to be one among the foremost catalytic instruments in generating momentous investment growth within the capital market. During this context, close monitoring and evaluation of mutual funds became essential. Therefore, choosing profitable mutual funds for investment may be a vital issue. This study deals with the equity mutual funds that are offered for investment by the varied fund houses in India, this study mainly focused on the performance of selected equity (large-cap, mid-cap, smallcap) open-end fund schemes in terms of a risk-return relationship. The most objective of this research work is to analyse the financial performance of selected open-end fund schemes through statistical parameters like (Jenson's alpha, beta, standard deviation, Sharpe ratio).

\section{RESEARCH METHODOLOGY}

\section{Research Objectives}

The main objective of the current research paper is to know current practices of selected Cement Industries for Sustainability Reporting. We are examining about different aspects of Sustainability of Organisation as well as Society at large.

\section{Research Design}

Data collection: We have used Secondary data for examining trend of Sustainability reporting of Cement Companies. Data has been collected from Annual reports of various Cement Manufacturing Companies. We had collected data from official websites of various Cement Manufacturing Companies.

\section{Sample Size}

We have selected four leading Cement Companies of the Country. All such companies holding more than 75\% market share of Cement Industry. All four Cement companies under the study are consider to be Market leader.

\section{Sustainable Aspects}

We have considered two main sustainable reporting aspects viz. Social Aspects and Environmental aspects.

\section{General Findings}

1. Ultratech Cement has clear-cut mission and Vision for Sustainable reporting. Over and above company also has target to be achieved in the span next five years which reflected in Quantity. 


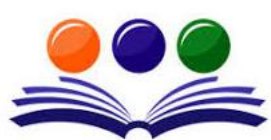

GRAND ACADEMIC PORTAL RESEARCH JOURNALS
A GLOBAL JOURNAL OF SOCIAL SCIENCES

( ISSN - 2581-5830 )

Impact Factor - SJIF - 4.998, IIFS - 4.375

Globally peer-reviewed and open access journal.

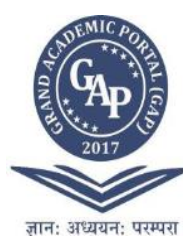

2. Ultratech Cement had considered Social and Environmental Aspects in discharging their Sustainable responsibility.

3. Initiatives in the area of Health Care, Education and Women Empowerment had been taken continuously for all the three years and its impact on society had been widen during the span of three years.

4. Company has emphasized on the impact of Social Initiatives. Hence, company has reported the impact of their initiatives in the various areas on Human Life effectively.

5. Firm had not reported the amount spend after various initiatives in the area of Social Aspects as well as Environment aspects.

6. Sensitivity towards different environment aspects had been reflected in the form of Use of Recycled Water, Reduction in Release of Carbon dioxide and land preservation.

7. Every year firm is increasing their efforts in the area of Environmental aspects of sustainability.

\section{Ambuja Cement}

1. Firm is sensitive towards Health Care, Education and Women Empowerment also. However, they are focusing more on Health Care and Education.

2. Firm has spent same amount of fund for women empowerment in all three years of study.

3. Measurement of initiatives of the firm in terms of touching lives or impact in the society is very important. However, firm had ignored such type of reporting and not reflecting any impact on the society either for Social aspects or Environmental aspects.

4. Over all amount spent on various social aspects is showing slightly decreasing trend in the span of three years.

5. Firm had not taken any initiatives for land improvement in all the three years of study.

6. Quantification of environmental aspects efforts had been reflected in the Sustainability reporting. Such reporting makes presentation more meaning full.

7. Efforts in the area of usage of recycled water for production of cement had been constantly increasing.

8. Air pollution control had been reported consistently but their efforts for such is not showing consistency at all.

\section{ACC Cement}

1. Inconsistency in reporting of firm has been observed in the span of last three years for various social aspects.

2. Firm has focused on Health Care, Education and Women Empowerment consistently and reported their initiatives in all three years.

3. Firm had not reported an amount spent for their social initiatives at all.

4. Impact of firm's initiatives on Human life has been reported effectively in last two years of study only.

5. Quantification of the firm's effort for several environmental aspects is not consistent at all. However, utilization of fresh water and Use of recycled water had been reported clearly.

6. Sensitivity towards land conservation as well as fresh air is much appreciable efforts.

7. Efforts in the area of land conservation and non-polluted air had been constantly increasing in span of last three years.

\section{Shree Cement}

1. Shree Cement had reported all the efforts in the area of social aspects with amount spent on such activities.

2. Impact of various social aspects had been reported since 2017-18 onwards for Health Care, Education and Women Empowerment.

3. Inconsistency in the reporting of social impact and amount spent had been observed in all three years of study.

4. On the basis of last three years data we can observe that there is constantly increase in the efforts of Health Care solution, Education Facilities and Women Empowerment.

5. There is no reporting of amount spent on various environment aspects of sustainability reporting.

6. Sensitivity towards Water Conservation, Land Conservation and Air pollution has been observed during all three years.

7. Utilization of recycled water in production process had been increasing slowly and gradually.

8. $\quad$ Reduction of release of Carbon Dioxide had been reported for all three years.

\section{SUGGESTIONS}

1. Sustainability reporting is not compulsory at all. Hence there is no universal format for reporting such activities of the firm. Hence it is advisable to adopt uniform reporting system. 


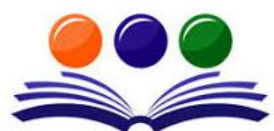

GRAND ACADEMIC PORTAL RESEARCH JOURNALS

A GLOBAL JOURNAL OF SOCIAL SCIENCES

( ISSN - 2581-5830 )

Impact Factor - SJIF - 4.998, IIFS - 4.375

Globally peer-reviewed and open access journal.

2. Different firms are presenting differently. Many firms are presenting with the pictures, charts, diagrams but consistency is missing in reporting style. Hence one should make presentation consistently.

3. Present reporting practices of all the cement industry firm is selective and not inclusive. It need to be inclusive so that one can have better understanding of initiatives of firm.

4. One should reflect the effect of Water Conservation or Land Conservation or Air Pollution control efforts in comparison with per unit of production in respective year.

5. One should present all initiatives of last two years. Hence user of financial reports can compare the efforts.

6. Mission and Vision of the Organisation towards Sustainable Development need to be reported compulsorily in every year for better understanding of efforts of the Organisation.

7. Organisations have decentralized production system (particularly) in case of Cement Manufacturing. Hence, it is advisable to report sustainable development efforts of firm on the basis of geographical areas.

8. Efforts of Holding Company and Subsidiary company need be reported separately for better understanding of the overall initiatives.

\section{CONCLUSION}

Sustainable reporting is one of the important aspect for Corporate reporting. Sustainable reporting provides information about organization's efforts in the direction of sustainable development of Organisation and society at large both. Though sustainable reporting is optional for companies in India Cement companies are following global standards of reporting. From there search work we can conclude that all the cement companies under the study are sensitive towards serval social issues. Over and above all such companies are reporting their initiatives towards sustainability since last three years. However, it has been observed that several companies are not reporting the impact of initiatives (in terms of number of human being affected). Hence, it has been concluded that financial reporting regulating authority need to develop different standards of Sustainable reporting for uniformity in reporting.

\section{REFERENCES}

[1] Goyal N. (2014). Corporate Sustainability Reporting Practices among Indian Companies - Myth or Reality. International Journal of Management and Social Sciences research Volume 3, No. 1, 54-60. http://citeseerx.ist.psu.edu/viewdoc/download?doi=10.1.1.407.5895\&rep=rep1\&type=pdf

[2] Frost G., Jones S., Loftus J. and Laan S. (2005). A Survey of sustainability reporting practices of Australian reporting entities. Australian Accounting Review 15, no. 35, 89-96. https://doi.org/10.1111/j.18352561.2005.tb00256.x

[3] Haimashree, P. J. (2014). A Comparative Perspective of Sustainability Reporting Practices in Indian \& Global firms. Journal of Business and Financial affairs, Research (2020), Volume 9, Issue 2. https://www.hilarispublisher.com/open-access/sustainability-reporting-practices-of-indian-corporatesector-a-comparative-analysis-50790.html

[4] Japee, G. P. ENVIRONMENTAL ACCOUNTING: DISCLOSURE PRACTICES OF SELECTED INDIAN COMPANIES.

[5] Japee, G. P. (2012). Study of environmental accounting and disclosure practices in listed Indian companies.

[6] Singh A., Gautam R. (2010). Corporate Social Responsibility practices in India. A study on top 500 companies. Global Business and Management Research: An international Journal, 2(1),41-56. https://www.researchgate.net/publication/264233703_Corporate_Social_Responsibility_Practices_in_India_A _Study_of_Top_500_Companies\#: :text=The\%20study\%20suggests\%20that\%20business,companies\%20were \%20reporting\%20on\%20CSR.

[7] Tripathi, S., \& Japee, D. G. P. (2020). Performance Evaluation of Selected Equity Mutual Funds in India. GAP GYAN-A GLOBAL JOURNAL OF SOCIAL SCIENCES. 


\section{A GLOBAL JOURNAL OF SOCIAL SCIENCES}

( ISSN - 2581-5830 )

Impact Factor - SJIF - 4.998, IIFS - 4.375

GRAND ACADEMIC PORTAL obally peer-reviewed and open access journal.

[8] Gunasekaran A., Singh K., Dubey R., Papadopoulos T. and Kumar V. (2015) Sustainable Production and Consumption. Elsevier, Volume 4, October 2015, Pages 62-71 https://doi.org/10.1016/j.spc.2015.08.005 


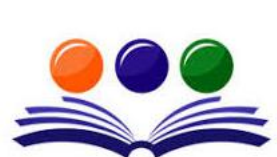

GRAND ACADEMIC PORTAL RESEARCH JOURNALS

A GLOBAL JOURNAL OF SOCIAL SCIENCES

( ISSN - 2581-5830 )

Impact Factor - SJIF - 4.998, IIFS - 4.375

Globally peer-reviewed and open access journal.

Annexure-1

\begin{tabular}{|c|c|c|c|c|c|c|c|c|}
\hline \multicolumn{9}{|c|}{ SUSTAINABILITY REPORTING BY ULTRATECH CEMENT DURING 2016-2018 } \\
\hline \multicolumn{3}{|c|}{ 2016-17 } & \multicolumn{3}{|c|}{ 2017-18 } & \multicolumn{3}{|c|}{ 2018-19 } \\
\hline $\begin{array}{c}\text { Status of } \\
\text { Reportin } \\
\mathrm{g}\end{array}$ & $\begin{array}{l}\text { Measuring } \\
\text { and } \\
\text { Reporting } \\
\text { Impact in } \\
\text { Society } \\
\text { (Touching } \\
\text { Human Life) }\end{array}$ & $\begin{array}{c}\text { Reporting } \\
\text { of } \\
\text { Amount } \\
\text { Spent }\end{array}$ & $\begin{array}{l}\text { Status of } \\
\text { Reporting }\end{array}$ & $\begin{array}{l}\text { Measuring and } \\
\text { Reporting Impact } \\
\text { in Society } \\
\text { (Touching } \\
\text { Human Life) }\end{array}$ & $\begin{array}{c}\text { Reporting } \\
\text { of } \\
\text { Amount } \\
\text { Spent }\end{array}$ & $\begin{array}{c}\text { Status of } \\
\text { Reporting }\end{array}$ & $\begin{array}{l}\text { Measuring } \\
\text { and } \\
\text { Reporting } \\
\text { Impact in } \\
\text { Society } \\
\text { (Touching } \\
\text { Human Life) }\end{array}$ & $\begin{array}{c}\begin{array}{c}\text { Reporting } \\
\text { of }\end{array} \\
\text { Amount } \\
\text { Spent }\end{array}$ \\
\hline Reported & 412738 & $\begin{array}{c}\text { Not } \\
\text { Reported }\end{array}$ & Reported & $2,80,292$ & $\begin{array}{c}\text { Not } \\
\text { Reported }\end{array}$ & Reported & $3,93,367$ & $\begin{array}{c}\text { Not } \\
\text { Reported }\end{array}$ \\
\hline Reported & 132419 & $\begin{array}{c}\text { Not } \\
\text { Reported }\end{array}$ & Reported & $1,75,907$ & $\begin{array}{c}\text { Not } \\
\text { Reported }\end{array}$ & Reported & $1,68,625$ & $\begin{array}{c}\text { Not } \\
\text { Reported }\end{array}$ \\
\hline Reported & 80,000 & $\begin{array}{c}\text { Not } \\
\text { Reported }\end{array}$ & Reported & 80,000 & $\begin{array}{c}\text { Not } \\
\text { Reported }\end{array}$ & Reported & 82,000 & $\begin{array}{c}\text { Not } \\
\text { Reported }\end{array}$ \\
\hline Reported & 12108 & $\begin{array}{c}\text { Not } \\
\text { Reported }\end{array}$ & Reported & 2500 & $\begin{array}{c}\text { Not } \\
\text { Reported }\end{array}$ & Reported & 8000 & $\begin{array}{c}\text { Not } \\
\text { Reported }\end{array}$ \\
\hline $\begin{array}{c}\text { Status of } \\
\text { Reportin } \\
\text { g }\end{array}$ & $\begin{array}{c}\text { Quantifying } \\
\text { Impact of } \\
\text { efforts on } \\
\text { Environmen } \\
t \\
\end{array}$ & $\begin{array}{c}\text { Reporting } \\
\text { of } \\
\text { Amount } \\
\text { Spent }\end{array}$ & $\begin{array}{l}\text { Status of } \\
\text { Reporting }\end{array}$ & $\begin{array}{c}\text { Quantifying } \\
\text { Impact of efforts } \\
\text { on Environment }\end{array}$ & $\begin{array}{c}\text { Reporting } \\
\text { of } \\
\text { Amount } \\
\text { Spent }\end{array}$ & $\begin{array}{l}\text { Status of } \\
\text { Reporting }\end{array}$ & $\begin{array}{c}\text { Quantifying } \\
\text { Impact of } \\
\text { efforts on } \\
\text { Environmen } \\
t \\
\end{array}$ & $\begin{array}{c}\text { Reporting } \\
\text { of } \\
\text { Amount } \\
\text { Spent }\end{array}$ \\
\hline Reported & $\begin{array}{c}16.33 \% \\
\text { WATER } \\
\text { RECYCLED \& } \\
\text { REUSED }\end{array}$ & $\begin{array}{c}\text { Not } \\
\text { Reported }\end{array}$ & Reported & $\begin{array}{l}\text { 15.12\% WATER } \\
\text { RECYCLED \& } \\
\text { REUSED }\end{array}$ & $\begin{array}{c}\text { Not } \\
\text { Reported }\end{array}$ & Reported & $\begin{array}{c}14.9 \% \\
\text { WATER } \\
\text { RECYCLED } \\
\text { OUT OF } \\
\text { TOTAL } \\
\text { WITHDRAWN }\end{array}$ & $\begin{array}{c}\text { Not } \\
\text { Reported }\end{array}$ \\
\hline Reported & $\begin{array}{c}2,86,840 \\
\text { SAPPLINGS } \\
\text { PLANTED }\end{array}$ & $\begin{array}{c}\text { Not } \\
\text { Reported }\end{array}$ & Reported & $\begin{array}{c}2,04,657 \text { SAPLING } \\
\text { S }\end{array}$ & $\begin{array}{c}\text { Not } \\
\text { Reported }\end{array}$ & Reported & $\begin{array}{c}\text { 3,15,645 } \\
\text { SAPPLINGS } \\
\text { PLANTED }\end{array}$ & $\begin{array}{c}\text { Not } \\
\text { Reported }\end{array}$ \\
\hline $\begin{array}{c}\text { Not } \\
\text { Reported }\end{array}$ & Not Reported & $\begin{array}{c}\text { Not } \\
\text { Reported }\end{array}$ & Reported & $\begin{array}{c}\text { REDUCED CO2 BY } \\
6.39 \mathrm{KG} / \mathrm{TON}\end{array}$ & $\begin{array}{c}\text { Not } \\
\text { Reported }\end{array}$ & Reported & $\begin{array}{l}18.46 \% \text { CO2 } \\
\text { REDUCTION } \\
\text { VS 2005-06 }\end{array}$ & $\begin{array}{c}\text { Not } \\
\text { Reported }\end{array}$ \\
\hline
\end{tabular}

Annexure-2

AMBUJA CEMENT'S SUSTAINABILITY REPORTING DURING 2016-2018

\begin{tabular}{|c|c|c|c|c|c|c|c|c|c|}
\hline & \multicolumn{3}{|l|}{ 2016-17 } & \multicolumn{3}{|l|}{ 2017-18 } & \multicolumn{3}{|l|}{ 2018-19 } \\
\hline $\begin{array}{l}\text { Different Aspects of } \\
\text { Sustainbility } \\
\text { Reporting }\end{array}$ & $\begin{array}{l}\text { Status } \\
\text { of } \\
\text { Reporti } \\
\text { ng }\end{array}$ & $\begin{array}{l}\text { Measuring } \\
\text { and } \\
\text { Reporting } \\
\text { Impact in } \\
\text { Society } \\
\text { (Touching } \\
\text { Human } \\
\text { Life) } \\
\end{array}$ & $\begin{array}{l}\text { Reporti } \\
\text { ng of } \\
\text { Amount } \\
\text { Spent } \\
\text { (In Rs. } \\
\text { Crores) }\end{array}$ & $\begin{array}{l}\text { Status } \\
\text { of } \\
\text { Reporti } \\
\text { ng }\end{array}$ & $\begin{array}{l}\text { Measuring } \\
\text { and } \\
\text { Reporting } \\
\text { Impact in } \\
\text { Society } \\
\text { (Touching } \\
\text { Human } \\
\text { Life) } \\
\end{array}$ & $\begin{array}{l}\text { Reporti } \\
\text { ng of } \\
\text { Amount } \\
\text { Spent } \\
\text { (In Rs. } \\
\text { Crores) }\end{array}$ & $\begin{array}{l}\text { Status } \\
\text { of } \\
\text { Reporti } \\
\text { ng }\end{array}$ & $\begin{array}{l}\text { Measuring } \\
\text { and } \\
\text { Reporting } \\
\text { Impact in } \\
\text { Society } \\
\text { (Touching } \\
\text { Human } \\
\text { Life) }\end{array}$ & $\begin{array}{l}\text { Reporti } \\
\text { ng of } \\
\text { Amount } \\
\text { Spent } \\
\text { (In Rs. } \\
\text { Crores) }\end{array}$ \\
\hline \multicolumn{10}{|l|}{ Social Aspects } \\
\hline $\begin{array}{l}\text { Initiatives in the } \\
\text { area of Health Care }\end{array}$ & $\begin{array}{l}\text { Reporte } \\
\text { d }\end{array}$ & $\begin{array}{l}\text { Not } \\
\text { Reported }\end{array}$ & 16 & $\begin{array}{l}\text { Reporte } \\
d\end{array}$ & $\begin{array}{l}\text { Not } \\
\text { Reported }\end{array}$ & 23 & $\begin{array}{l}\text { Reporte } \\
\text { d }\end{array}$ & $3,33,600$ & 17 \\
\hline
\end{tabular}




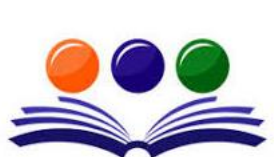

GRAND ACADEMIC PORTAL RESEARCH JOURNAL

\section{A GLOBAL JOURNAL OF SOCIAL SCIENCES}

( ISSN - 2581-5830)

Impact Factor - SJIF - 4.998, IIFS - 4.375

Globally peer-reviewed and open access journal.

\begin{tabular}{|c|c|c|c|c|c|c|c|c|c|}
\hline $\begin{array}{l}\text { Inititves in the area } \\
\text { of Education }\end{array}$ & $\begin{array}{l}\text { Reporte } \\
\text { d }\end{array}$ & $\begin{array}{l}\text { Not } \\
\text { Reported }\end{array}$ & 19 & $\begin{array}{l}\text { Reporte } \\
\text { d }\end{array}$ & $\begin{array}{l}\text { Not } \\
\text { Reported }\end{array}$ & 12 & $\begin{array}{l}\text { Reporte } \\
\text { d }\end{array}$ & $\begin{array}{l}\text { Not } \\
\text { Reported }\end{array}$ & 9 \\
\hline $\begin{array}{l}\text { Initiatives in the } \\
\text { area of Water } \\
\text { Avialbility } \\
\text { Water Management }\end{array}$ & $\begin{array}{l}\text { Reporte } \\
\text { d }\end{array}$ & $\begin{array}{l}\text { Not } \\
\text { Reported }\end{array}$ & 14 & $\begin{array}{l}\text { Reporte } \\
\text { d }\end{array}$ & $\begin{array}{l}\text { Not } \\
\text { Reported }\end{array}$ & 15 & $\begin{array}{l}\text { Reporte } \\
\text { d }\end{array}$ & $\begin{array}{l}\text { Not } \\
\text { Reported }\end{array}$ & 18 \\
\hline \multirow[t]{2}{*}{$\begin{array}{l}\text { Initiative in the area } \\
\text { of Women } \\
\text { Empowerment }\end{array}$} & $\begin{array}{l}\text { Reporte } \\
\text { d }\end{array}$ & $\begin{array}{l}\text { Not } \\
\text { Reported }\end{array}$ & 3 & $\begin{array}{l}\text { Reporte } \\
\text { d }\end{array}$ & $\begin{array}{l}\text { Not } \\
\text { Reported }\end{array}$ & 3 & $\begin{array}{l}\text { Reporte } \\
\text { d }\end{array}$ & $\begin{array}{l}\text { Not } \\
\text { Reported }\end{array}$ & 3 \\
\hline & & & 52 & & & 53 & & & 47 \\
\hline $\begin{array}{l}\text { Environmental } \\
\text { Aspects }\end{array}$ & $\begin{array}{l}\text { Status } \\
\text { of } \\
\text { Reporti } \\
\text { ng }\end{array}$ & $\begin{array}{l}\text { Quantifyi } \\
\text { ng Impact } \\
\text { of efforts } \\
\text { on } \\
\text { Environm } \\
\text { ent }\end{array}$ & $\begin{array}{l}\text { Reporti } \\
\text { ng of } \\
\text { Amount } \\
\text { Spent }\end{array}$ & $\begin{array}{l}\text { Status } \\
\text { of } \\
\text { Reporti } \\
\text { ng }\end{array}$ & $\begin{array}{l}\text { Quantifyi } \\
\text { ng Impact } \\
\text { of efforts } \\
\text { on } \\
\text { Environm } \\
\text { ent }\end{array}$ & $\begin{array}{l}\text { Reporti } \\
\text { ng of } \\
\text { Amount } \\
\text { Spent }\end{array}$ & $\begin{array}{l}\text { Status } \\
\text { of } \\
\text { Reporti } \\
\text { ng }\end{array}$ & $\begin{array}{l}\text { Quantifyi } \\
\text { ng Impact } \\
\text { of efforts } \\
\text { on } \\
\text { Environm } \\
\text { ent }\end{array}$ & $\begin{array}{l}\text { Reporti } \\
\text { ng of } \\
\text { Amount } \\
\text { Spent }\end{array}$ \\
\hline $\begin{array}{l}\text { Use of Recycled } \\
\text { Water }\end{array}$ & $\begin{array}{l}\text { Reporte } \\
\text { d }\end{array}$ & $\begin{array}{l}12.8 \% \\
\text { WATER } \\
\text { RECYCLED } \\
\text { OUT OF } \\
\text { TOTAL } \\
\text { WITHDRA } \\
\text { WN }\end{array}$ & $\begin{array}{l}\text { Not } \\
\text { Reporte } \\
d\end{array}$ & $\begin{array}{l}\text { Reporte } \\
\text { d }\end{array}$ & $\begin{array}{l}13.7 \% \\
\text { WATER } \\
\text { RECYCLED } \\
\text { OUT OF } \\
\text { TOTAL } \\
\text { WITHDRA } \\
\text { WN }\end{array}$ & $\begin{array}{l}\text { Not } \\
\text { Reporte } \\
\text { d }\end{array}$ & $\begin{array}{l}\text { Reporte } \\
\text { d }\end{array}$ & $\begin{array}{l}15 \% \\
\text { WATER } \\
\text { RECYCLED } \\
\text { OUT OF } \\
\text { TOTAL } \\
\text { WITHDRA } \\
\text { WN }\end{array}$ & $\begin{array}{l}\text { Not } \\
\text { Reporte } \\
\text { d }\end{array}$ \\
\hline $\begin{array}{l}\text { Initiative for Land } \\
\text { Improvement }\end{array}$ & $\begin{array}{l}\text { Not } \\
\text { Reporte } \\
\text { d }\end{array}$ & $\begin{array}{l}\text { Not } \\
\text { Reported }\end{array}$ & $\begin{array}{l}\text { Not } \\
\text { Reporte } \\
\text { d }\end{array}$ & $\begin{array}{l}\text { Not } \\
\text { Reporte } \\
\text { d }\end{array}$ & $\begin{array}{l}\text { Not } \\
\text { Reported }\end{array}$ & $\begin{array}{l}\text { Not } \\
\text { Reporte } \\
\text { d }\end{array}$ & $\begin{array}{l}\text { Not } \\
\text { Reporte } \\
\text { d }\end{array}$ & $\begin{array}{l}\text { Not } \\
\text { Reported }\end{array}$ & $\begin{array}{l}\text { Not } \\
\text { Reporte } \\
\text { d }\end{array}$ \\
\hline $\begin{array}{l}\text { Initiative for Air } \\
\text { Protection/Improve } \\
\text { ment of Air Qualilty }\end{array}$ & $\begin{array}{l}\text { Not } \\
\text { Reporte } \\
\text { d }\end{array}$ & $\begin{array}{l}31.4 \% \\
\text { REDUCTIO } \\
\mathrm{N} \text { IN CO2 } \\
\text { EMISSION } \\
\text { VS } 1990\end{array}$ & $\begin{array}{l}\text { Not } \\
\text { Reporte } \\
\text { d }\end{array}$ & $\begin{array}{l}\text { Not } \\
\text { Reporte } \\
\text { d }\end{array}$ & $\begin{array}{l}5 \% \\
\text { REDUCTIO } \\
\text { N IN CO2 } \\
\text { EMMISSIO } \\
\text { N VS } 2015\end{array}$ & $\begin{array}{l}\text { Not } \\
\text { Reporte } \\
\text { d }\end{array}$ & $\begin{array}{l}\text { Reporte } \\
\text { d }\end{array}$ & $\begin{array}{l}31.26 \% \\
\text { REDUCTIO } \\
N \text { IN CO2 } \\
\text { VS } 1990\end{array}$ & $\begin{array}{l}\text { Not } \\
\text { Reporte } \\
\text { d }\end{array}$ \\
\hline
\end{tabular}

Annexure-3

SUSTAINABILITY REPORTING BY ACC CEMENT DURING 2016-2018

\begin{tabular}{|c|c|c|c|c|c|c|c|c|c|}
\hline \multirow[b]{2}{*}{$\begin{array}{l}\text { Different Aspects of } \\
\text { Sustainbility } \\
\text { Reporting }\end{array}$} & \multicolumn{3}{|l|}{ 2016-17 } & \multicolumn{3}{|l|}{ 2017-18 } & \multicolumn{3}{|l|}{ 2018-19 } \\
\hline & $\begin{array}{l}\text { Status } \\
\text { of } \\
\text { Reporti } \\
\text { ng }\end{array}$ & $\begin{array}{l}\text { Measuring } \\
\text { and } \\
\text { Reporting } \\
\text { Impact in } \\
\text { Society } \\
\text { (Touching } \\
\text { Human } \\
\text { Life) }\end{array}$ & $\begin{array}{l}\text { Reporti } \\
\text { ng of } \\
\text { Amount } \\
\text { Spent } \\
\text { (In Rs. } \\
\text { Crores) }\end{array}$ & $\begin{array}{l}\text { Status } \\
\text { of } \\
\text { Reporti } \\
\text { ng }\end{array}$ & $\begin{array}{l}\text { Measurin } \\
\text { g and } \\
\text { Reporting } \\
\text { Impact in } \\
\text { Society } \\
\text { (Touching } \\
\text { Human } \\
\text { Life) } \\
\end{array}$ & $\begin{array}{l}\text { Reporti } \\
\text { ng of } \\
\text { Amount } \\
\text { Spent } \\
\text { (In Rs. } \\
\text { Crores) }\end{array}$ & $\begin{array}{l}\text { Status } \\
\text { of } \\
\text { Reporti } \\
\text { ng }\end{array}$ & $\begin{array}{l}\text { Measuring } \\
\text { and } \\
\text { Reporting } \\
\text { Impact in } \\
\text { Society } \\
\text { (Touching } \\
\text { Human } \\
\text { Life) }\end{array}$ & $\begin{array}{l}\text { Reporti } \\
\text { ng of } \\
\text { Amount } \\
\text { Spent } \\
\text { (In Rs. } \\
\text { Crores) }\end{array}$ \\
\hline \multicolumn{10}{|l|}{ Social Aspects } \\
\hline $\begin{array}{l}\text { Initiatives in the } \\
\text { area of Health Care }\end{array}$ & $\begin{array}{l}\text { Reporte } \\
\text { d }\end{array}$ & $\begin{array}{l}\text { 10,000+ } \\
\text { STUDENTS } \\
\text { GIVEN } \\
\text { HEALTH } \\
\text { TRAINING }\end{array}$ & 4.51 & $\begin{array}{l}\text { Reporte } \\
\text { d }\end{array}$ & 43,412 & $\begin{array}{l}\text { Not } \\
\text { Reporte } \\
\text { d }\end{array}$ & $\begin{array}{l}\text { Reporte } \\
\text { d }\end{array}$ & $4,80,906$ & $\begin{array}{l}\text { Not } \\
\text { Reporte } \\
\text { d }\end{array}$ \\
\hline $\begin{array}{l}\text { Inititves in the area } \\
\text { of Education }\end{array}$ & $\begin{array}{l}\text { Reporte } \\
\text { d }\end{array}$ & 67,235 & $\begin{array}{l}\text { Not } \\
\text { Reporte } \\
\text { d }\end{array}$ & $\begin{array}{l}\text { Reporte } \\
\mathrm{d}\end{array}$ & 32,012 & $\begin{array}{l}\text { Not } \\
\text { Reporte } \\
\text { d }\end{array}$ & $\begin{array}{l}\text { Reporte } \\
\mathrm{d}\end{array}$ & 76,472 & $\begin{array}{l}\text { Not } \\
\text { Reporte } \\
\text { d }\end{array}$ \\
\hline
\end{tabular}




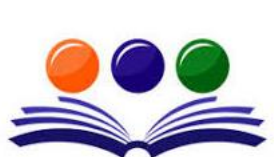

GRAND ACADEMIC PORTAL RESEARCH JOURNAL

\section{A GLOBAL JOURNAL OF SOCIAL SCIENCES}

( ISSN - 2581-5830 )

Impact Factor - SJIF - 4.998, IIFS - 4.375

Globally peer-reviewed and open access journal.

जान: अध्यगन: पग्माग

\begin{tabular}{|c|c|c|c|c|c|c|c|c|c|}
\hline $\begin{array}{l}\text { Initiatives in the } \\
\text { area of Water } \\
\text { Avialbility r and } \\
\text { Water Management }\end{array}$ & $\begin{array}{l}\text { Reporte } \\
\text { d }\end{array}$ & $\begin{array}{l}200 \\
\text { VILLAGES }\end{array}$ & $\begin{array}{l}\text { Not } \\
\text { Reporte } \\
\text { d }\end{array}$ & $\begin{array}{l}\text { Reporte } \\
\text { d }\end{array}$ & 55,240 & $\begin{array}{l}\text { Not } \\
\text { Reporte } \\
\text { d }\end{array}$ & $\begin{array}{l}\text { Reporte } \\
\text { d }\end{array}$ & 176015 & $\begin{array}{l}\text { Not } \\
\text { Reporte } \\
\text { d }\end{array}$ \\
\hline $\begin{array}{l}\text { Initiative in the } \\
\text { area of Women } \\
\text { Empowerment }\end{array}$ & $\begin{array}{l}\text { Reporte } \\
\text { d }\end{array}$ & & 2.26 & $\begin{array}{l}\text { Reporte } \\
\text { d }\end{array}$ & 6647 & $\begin{array}{l}\text { Not } \\
\text { Reporte } \\
d\end{array}$ & $\begin{array}{l}\text { Reporte } \\
\text { d }\end{array}$ & 5399 & $\begin{array}{l}\text { Not } \\
\text { Reporte } \\
d\end{array}$ \\
\hline $\begin{array}{l}\text { Environmental } \\
\text { Aspects }\end{array}$ & $\begin{array}{l}\text { Status } \\
\text { of } \\
\text { Reporti } \\
\text { ng }\end{array}$ & $\begin{array}{l}\text { Quantifyin } \\
\text { g Impact of } \\
\text { efforts on } \\
\text { Environme } \\
\text { nt }\end{array}$ & $\begin{array}{l}\text { Reporti } \\
\text { ng of } \\
\text { Amount } \\
\text { Spent }\end{array}$ & $\begin{array}{l}\text { Status } \\
\text { of } \\
\text { Reporti } \\
\text { ng }\end{array}$ & $\begin{array}{l}\text { Quantifyi } \\
\text { ng Impact } \\
\text { of efforts } \\
\text { on } \\
\text { Environm } \\
\text { ent }\end{array}$ & $\begin{array}{l}\text { Reporti } \\
\text { ng of } \\
\text { Amount } \\
\text { Spent }\end{array}$ & $\begin{array}{l}\text { Status } \\
\text { of } \\
\text { Reporti } \\
\text { ng }\end{array}$ & $\begin{array}{l}\text { Quantifyin } \\
\text { g Impact of } \\
\text { efforts on } \\
\text { Environme } \\
\text { nt }\end{array}$ & $\begin{array}{l}\text { Reporti } \\
\text { ng of } \\
\text { Amount } \\
\text { Spent }\end{array}$ \\
\hline $\begin{array}{l}\text { Use of Recycled } \\
\text { Water }\end{array}$ & $\begin{array}{l}\text { Reporte } \\
\text { d }\end{array}$ & $\begin{array}{l}\text { 19\% FRESH } \\
\text { WATER } \\
\text { WITHDRA } \\
\text { WAL } \\
\text { REDUCTIO } \\
\mathrm{N} \text { TO LAST } \\
\text { YR, } 1.31 \\
\text { MN M3 } \\
\text { WATER } \\
\text { TREATED \& } \\
\text { REUSED }\end{array}$ & $\begin{array}{l}\text { Not } \\
\text { Reporte } \\
\text { d }\end{array}$ & $\begin{array}{l}\text { Reporte } \\
\text { d }\end{array}$ & $\begin{array}{l}\text { 1.63 mn } \\
\mathrm{m} 3 \\
\text { WATER } \\
\text { TREATED } \\
\text { \& REUSED }\end{array}$ & $\begin{array}{l}\text { Not } \\
\text { Reporte } \\
\text { d }\end{array}$ & $\begin{array}{l}\text { Reporte } \\
\text { d }\end{array}$ & $\begin{array}{l}\text { 16\% } \\
\text { FRESHWAT } \\
\text { ER } \\
\text { WITHDRA } \\
\text { WAL } \\
\text { REDUCTIO } \\
\text { N T0 LAST } \\
\text { YEAR, 12\% } \\
\text { OF TOTAL } \\
\text { WATER } \\
\text { CONSUMED } \\
\text { RECYCLED }\end{array}$ & $\begin{array}{l}\text { Not } \\
\text { Reporte } \\
\text { d }\end{array}$ \\
\hline $\begin{array}{l}\text { Initiative for Land } \\
\text { Improvement }\end{array}$ & $\begin{array}{l}\text { Reporte } \\
\text { d }\end{array}$ & $\begin{array}{l}\text { 1.5 LACS + } \\
\text { TREES } \\
\text { PLANTED }\end{array}$ & $\begin{array}{l}\text { Not } \\
\text { Reporte } \\
\text { d }\end{array}$ & $\begin{array}{l}\text { Reporte } \\
\text { d }\end{array}$ & $\begin{array}{l}758 \quad \text { HA } \\
\text { REHAB } \\
\text { AREA, } \\
51465 \\
\text { SOIL } \\
\text { CONSERVE } \\
\text { D }\end{array}$ & $\begin{array}{l}\text { Not } \\
\text { Reporte } \\
\text { d }\end{array}$ & $\begin{array}{l}\text { Reporte } \\
\text { d }\end{array}$ & $\begin{array}{l}\text { 81,416 MT } \\
\text { SOIL } \\
\text { CONSERVE } \\
\text { D }\end{array}$ & $\begin{array}{l}\text { Not } \\
\text { Reporte } \\
\text { d }\end{array}$ \\
\hline $\begin{array}{l}\text { Initiative for Air } \\
\text { Protection/Improve } \\
\text { ment of Air Qualilty }\end{array}$ & $\begin{array}{l}\text { Reporte } \\
\text { d }\end{array}$ & $\begin{array}{l}35 \% \quad \text { CO2 } \\
\text { REDUCED } \\
\text { VS } 1990\end{array}$ & $\begin{array}{l}\text { Not } \\
\text { Reporte } \\
\text { d }\end{array}$ & $\begin{array}{l}\text { Reporte } \\
\text { d }\end{array}$ & $\begin{array}{l}\text { 3,622 MT } \\
\text { C02 } \\
\text { AVOIDED }\end{array}$ & $\begin{array}{l}\text { Not } \\
\text { Reporte } \\
\text { d }\end{array}$ & $\begin{array}{l}\text { Reporte } \\
\text { d }\end{array}$ & $\begin{array}{l}\text { 5,730MT } \\
\text { CO2 } \\
\text { AVOIDED }\end{array}$ & $\begin{array}{l}\text { Not } \\
\text { Reporte } \\
\text { d }\end{array}$ \\
\hline
\end{tabular}

Annexure-4

\begin{tabular}{|c|c|c|c|c|c|c|c|c|c|}
\hline \multicolumn{10}{|c|}{ SUSTAINABILITY REPORTING BY SHREE CEMENT DURING 2016-2018 } \\
\hline \multirow[b]{2}{*}{$\begin{array}{l}\text { Different Aspects of } \\
\text { Sustainbility } \\
\text { Reporting }\end{array}$} & \multicolumn{3}{|l|}{$2016-17$} & \multicolumn{3}{|l|}{ 2017-18 } & \multicolumn{3}{|l|}{ 2018-19 } \\
\hline & $\begin{array}{l}\text { Status } \\
\text { of } \\
\text { Reporti } \\
\text { ng }\end{array}$ & $\begin{array}{l}\text { Measuring } \\
\text { and } \\
\text { Reporting } \\
\text { Impact in } \\
\text { Society } \\
\text { (Touching } \\
\text { Human } \\
\text { Life) }\end{array}$ & $\begin{array}{l}\text { Reporti } \\
\text { ng of } \\
\text { Amount } \\
\text { Spent } \\
\text { (In } \\
\text { Million } \\
\text { Rs.) }\end{array}$ & $\begin{array}{l}\text { Status of } \\
\text { Reporti } \\
\text { ng }\end{array}$ & $\begin{array}{l}\text { Measurin } \\
\text { g and } \\
\text { Reporting } \\
\text { Impact in } \\
\text { Society } \\
\text { (Touching } \\
\text { Human } \\
\text { Life) }\end{array}$ & $\begin{array}{l}\text { Reporti } \\
\text { ng of } \\
\text { Amount } \\
\text { Spent } \\
\text { (In } \\
\text { Million } \\
\text { Rs.) }\end{array}$ & $\begin{array}{l}\text { Status } \\
\text { of } \\
\text { Reporti } \\
\text { ng }\end{array}$ & $\begin{array}{l}\text { Measurin } \\
\text { g and } \\
\text { Reporting } \\
\text { Impact in } \\
\text { Society } \\
\text { (Touching } \\
\text { Human } \\
\text { Life) }\end{array}$ & $\begin{array}{l}\text { Reporti } \\
\text { ng of } \\
\text { Amount } \\
\text { Spent } \\
\text { (In } \\
\text { Million } \\
\text { Rs.) }\end{array}$ \\
\hline \multicolumn{10}{|l|}{ Social Aspects } \\
\hline $\begin{array}{l}\text { Initiatives in the } \\
\text { area of Health Care }\end{array}$ & $\begin{array}{l}\text { Reporte } \\
\text { d }\end{array}$ & $\begin{array}{l}\text { Not } \\
\text { Reported }\end{array}$ & 1.73 & $\begin{array}{l}\text { Not } \\
\text { Reported }\end{array}$ & 29,620 & $\begin{array}{l}\text { Not } \\
\text { Reporte } \\
\text { d }\end{array}$ & $\begin{array}{l}\text { Reporte } \\
\text { d }\end{array}$ & $1,56,703$ & 84.6 \\
\hline
\end{tabular}




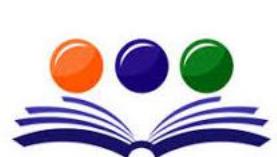

GRAND ACADEMIC PORTAL RESEARCH JOURNAL

\section{A GLOBAL JOURNAL OF SOCIAL SCIENCES}

( ISSN - 2581-5830)

Impact Factor - SJIF - 4.998, IIFS - 4.375

Globally peer-reviewed and open access journal.

जान: अध्यगन: पग्मग

\begin{tabular}{|c|c|c|c|c|c|c|c|c|c|}
\hline $\begin{array}{l}\text { Inititves in the area } \\
\text { of Education }\end{array}$ & $\begin{array}{l}\text { Reporte } \\
\text { d }\end{array}$ & $\begin{array}{l}\text { Not } \\
\text { Reported }\end{array}$ & 11.38 & $\begin{array}{l}\text { Not } \\
\text { Reported }\end{array}$ & 17937 & 70.9 & $\begin{array}{l}\text { Reporte } \\
\text { d }\end{array}$ & 9675 & 13.55 \\
\hline $\begin{array}{l}\text { Initiatives in the } \\
\text { area of } \text { Water } \\
\text { Avialbility } \\
\text { Water Management }\end{array}$ & $\begin{array}{l}\text { Reporte } \\
\text { d }\end{array}$ & $\begin{array}{l}\text { Not } \\
\text { Reported }\end{array}$ & 15.4 & $\begin{array}{l}\text { Not } \\
\text { Reported }\end{array}$ & $\begin{array}{l}\text { Not } \\
\text { Reported }\end{array}$ & 27.5 & $\begin{array}{l}\text { Reporte } \\
\text { d }\end{array}$ & 14401 & $\begin{array}{l}\text { Not } \\
\text { Reporte } \\
\text { d }\end{array}$ \\
\hline $\begin{array}{l}\text { Initiative in the } \\
\text { area of Women } \\
\text { Empowerment }\end{array}$ & $\begin{array}{l}\text { Reporte } \\
\text { d }\end{array}$ & $\begin{array}{l}\text { Not } \\
\text { Reported }\end{array}$ & 5.4 & $\begin{array}{l}\text { Not } \\
\text { Reported }\end{array}$ & 2124 & 13.3 & $\begin{array}{l}\text { Reporte } \\
\text { d }\end{array}$ & $\begin{array}{l}\text { Not } \\
\text { Reported }\end{array}$ & 12.7 \\
\hline $\begin{array}{l}\text { Environmental } \\
\text { Aspects }\end{array}$ & $\begin{array}{l}\text { Status } \\
\text { of } \\
\text { Reporti } \\
\text { ng }\end{array}$ & $\begin{array}{l}\text { Quantifyin } \\
\text { g Impact of } \\
\text { efforts on } \\
\text { Environme } \\
\text { nt }\end{array}$ & $\begin{array}{l}\text { Reporti } \\
\text { ng of } \\
\text { Amount } \\
\text { Spent }\end{array}$ & $\begin{array}{l}\text { Status of } \\
\text { Reporti } \\
\text { Not } \\
\text { Reporte } \\
\text { d g }\end{array}$ & $\begin{array}{l}\text { Quantifyi } \\
\text { ng Impact } \\
\text { of efforts } \\
\text { on } \\
\text { Environm } \\
\text { ent }\end{array}$ & $\begin{array}{l}\text { Reporti } \\
\text { ng of } \\
\text { Amount } \\
\text { Spent }\end{array}$ & $\begin{array}{l}\text { Status } \\
\text { of } \\
\text { Reporti } \\
\text { ng }\end{array}$ & $\begin{array}{l}\text { Quantifyi } \\
\text { ng Impact } \\
\text { of efforts } \\
\text { on } \\
\text { Environm } \\
\text { ent }\end{array}$ & $\begin{array}{l}\text { Reporti } \\
\text { ng of } \\
\text { Amount } \\
\text { Spent }\end{array}$ \\
\hline $\begin{array}{l}\text { Use of Recycled } \\
\text { Water }\end{array}$ & $\begin{array}{l}\text { Reporte } \\
\text { d }\end{array}$ & $\begin{array}{l}0.25 \text { MN M3 } \\
\text { WATER } \\
\text { RECYCLED, } \\
11 \% \\
\text { RECYCLED } \\
\text { OF TOTAL } \\
\text { WITHDRA } \\
\text { WAN }\end{array}$ & $\begin{array}{l}\text { Not } \\
\text { Reporte } \\
\text { d }\end{array}$ & Reported & $\begin{array}{l}0.28 \quad \text { MN } \\
\text { M3 } \\
\text { WATER } \\
\text { RECYCLED }\end{array}$ & $\begin{array}{l}\text { Not } \\
\text { Reporte } \\
\text { d }\end{array}$ & $\begin{array}{l}\text { Reporte } \\
\text { d }\end{array}$ & $\begin{array}{l}0.32 \quad \text { MN } \\
\text { M3 } \\
\text { WATER } \\
\text { RECYVLE, }\end{array}$ & $\begin{array}{l}\text { Not } \\
\text { Reporte } \\
\text { d }\end{array}$ \\
\hline $\begin{array}{l}\text { Initiative for Land } \\
\text { Improvement }\end{array}$ & $\begin{array}{l}\text { Reporte } \\
\text { d }\end{array}$ & $\begin{array}{l}188216 \\
\text { SAPLINGS } \\
\text { PLANTED }\end{array}$ & $\begin{array}{l}\text { Not } \\
\text { Reporte } \\
\text { d }\end{array}$ & Reported & $\begin{array}{l}90543 \\
\text { SAPLINGS } \\
\text { PLANTED }\end{array}$ & $\begin{array}{l}\text { Not } \\
\text { Reporte } \\
\text { d }\end{array}$ & $\begin{array}{l}\text { Reporte } \\
\text { d }\end{array}$ & $\begin{array}{l}85008 \\
\text { SAPLINGS } \\
\text { PLANTED }\end{array}$ & $\begin{array}{l}\text { Not } \\
\text { Reporte } \\
\text { d }\end{array}$ \\
\hline $\begin{array}{l}\text { Initiative for } \text { Air } \\
\text { Protection/Improv } \\
\text { ement of } \quad \text { Air } \\
\text { Qualilty }\end{array}$ & $\begin{array}{l}\text { Reporte } \\
\text { d }\end{array}$ & $\begin{array}{l}41.33 \% \\
\text { CO2 } \\
\text { REDUCED } \\
\text { VS } 1990\end{array}$ & $\begin{array}{l}\text { Not } \\
\text { Reporte } \\
\text { d }\end{array}$ & Reported & $\begin{array}{l}45 \% \quad \text { CO2 } \\
\text { LESS } \\
\text { EMITTED } \\
\text { VS } 1990\end{array}$ & $\begin{array}{l}\text { Not } \\
\text { Reporte } \\
\text { d }\end{array}$ & $\begin{array}{l}\text { Reporte } \\
\text { d }\end{array}$ & $\begin{array}{l}42.6 \% \\
\text { LESS VO2 } \\
1990\end{array}$ & $\begin{array}{l}\text { Not } \\
\text { Reporte } \\
\text { d }\end{array}$ \\
\hline
\end{tabular}

